Use of Impression Management Tactics in Professional Communication for Job Interviews among Graduate Students

Isai Amutan Krishnan, Narentheren Kaliappen, Vimala Davy G. Ramiah, Hoviyashree Anbalagan, Randeep Singh Sidhu, Saravanan Munian

To Link this Article: http://dx.doi.org/10.6007/IJARBSS/v12-i1/12281

DOI:10.6007/IJARBSS/v12-i1/12281

Received: 13 November 2021, Revised: 16 December 2021, Accepted: 04 January 2022

Published Online: 29 January 2022

In-Text Citation: (Krishnan et al., 2022)

To Cite this Article: Krishnan, I. A., Kaliappen, N., Ramiah, V. D. G., Anbalagan, H., Sidhu, R. S., \& Munian, S. (2022). Use of Impression Management Tactics in Professional Communication for Job Interviews among Graduate Students. International Journal of Academic Research in Business and Social Sciences, 12(1), 2078-2097.

Copyright: (c) 2022 The Author(s)

Published by Human Resource Management Academic Research Society (www.hrmars.com)

This article is published under the Creative Commons Attribution (CC BY 4.0) license. Anyone may reproduce, distribute, translate and create derivative works of this article (for both commercial and non0-commercial purposes), subject to full attribution to the original publication and authors. The full terms of this license may be seen at: http://creativecommons.org/licences/by/4.0/legalcode

Vol. 12, No. 1, 2022, Pg. 2078- 2097

Full Terms \& Conditions of access and use can be found at http://hrmars.com/index.php/pages/detail/publication-ethics 


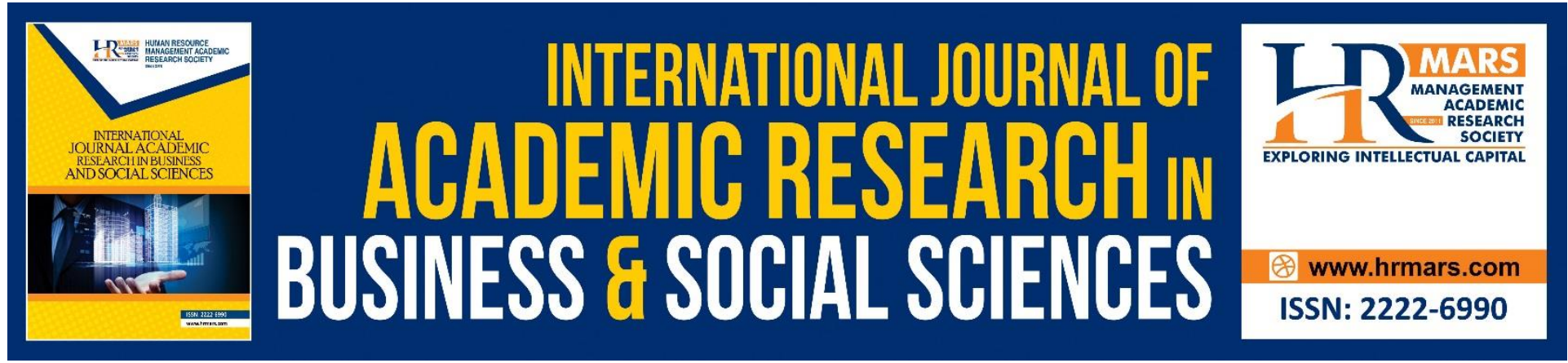

\title{
Use of Impression Management Tactics in Professional Communication for Job Interviews Among Graduate Students
}

\author{
Isai Amutan Krishnan \\ Perdana University, School of Liberal Arts and Science and Technology \\ Email: isai.amutan@perdanauniversity.edu.my, amuthan.isai@gmail.com \\ Narentheren Kaliappen \\ School of International Studies, University Utara Malaysia \\ Email: narentheren@uum.edu.my \\ Vimala Davy G. Ramiah \\ Institut Aminuddin Baki Sarawak Branch \\ Email: vimala@iab.edu.my \\ Hoviyashree Anbalagan \\ Wembley Academy \\ Email: hoviyashree.anbalagan@gmail.com
}

Randeep Singh Sidhu

Perdana University, School of Liberal Arts and Science and Technology

Email: randeep@perdanauniversity.edu.my,randeeproy89@yahoo.com

\author{
Saravanan Munian \\ SRJKT Ganesar Serdang, Kedah \\ Email: dr.saravananshiva@gmail.com
}

\begin{abstract}
This study investigated the impression management techniques (IMTs) used by fresh graduates in job interviews. Job interview data from twenty-five candidates were analysed qualitatively. The focus of analysis was on five aspects of impression management tactics namely self-focus, self-presentation, exemplifications, entitlements, and enhancements. It was found that all twenty candidates were in the poor ( $n=19 ; 60 \%)$, fair ( $n=9 ; 36 \%)$, and average $(n=6 ; 4 \%)$ categories, with none in the good or excellent category. This study can benefit candidates by demonstrating that educational qualifications are not the only important criterion for success in a job interview.
\end{abstract}


Keywords: Impression Management Tactics, Job Interviews, Fresh Graduates

\section{Introduction}

Job interviews are professional communications between a potential employer and job applicants to determine their suitability for a particular job. Certain skills are required to conduct a proper communication in job interviews, (Holmes, 1995). The most significant skill that affects the evaluation procedure of an interview is the impression skills, as they determine the views of the interviewers towards the candidate (Lopez \& Fletcher, 2004; Cheung et al. (2017) In the hiring process, the impression management techniques (IMT) of candidates can result in favourable evaluations by interviewers and positively influence the hiring decisions (Kacmar \& Delery 1992), although not everyone uses high-level IMT (Jacobs, 2003; Turnley, 2001; Sanhez \& Gou, 2005).

The Malaysian National Graduate Employability Blueprint 2012-2017 highlighted that most fresh graduates have difficulty creating favourable impressions in job interviews (Ministry of Higher Education of Malaysia [MHEM], 2019). Baqutayan et al. (2019) and Ahmed et al. (2019) also found that fresh graduates lacked skills in presenting their positive qualities (e.g., achievements, capabilities, responsibilities) and struggled to demonstrate their confidence to the interviewer.

Hence, IMT are vital attributes that can determine a candidate's success but are frequently overlooked. As MHEM (2019) noted, appropriate training in IMT for job seekers who attend interviews, are of paramount important in obtaining jobs. Hence, this study examined the extent to which IMT are depicted by fresh graduates during their job interviews.

\section{Professional Communication in Job Interviews}

According to Holmes and Riddiford (2009), based on the workplace context, professional communication is one of the tools required to expand business globally. They further noted that, organisations and corporate sectors identified that professional communication is one of the essential tools for recruiting employees into their organisation. If the employees have excellent communication skills, businesses are successful in their business. Hence, professional communications are guided by professional ethics that have some common capabilities between two individuals to achieve some specific objectives. Studies conducted by Coffelt et al (2016); Jensen (2003); Kwok (2004); Huang (2013); Krishnan and Srinivas (2014); Hamid et al (2014); Madziya et al (2016); Kenayathulla et al (2019), Majid et al (2020) on similar objectives found that professional communications would be helpful to evaluate a candidate's employability skills which would be helpful for the growth of organisations.

\section{Impression Management Tactics}

Goftman $(1959 ; 1972)$ argued that IMTs are one of the indispensable tools for social interactions (see Table 1). Goffman proposed a dramaturgical viewpoint of societal discourse, where individuals are construed to be actors who participate in multiple situations in the presence of an audience to shape meaning concerning the settings. Goftman further stated that IMTs are significant in job interviews, and if candidates are to become employees, then management and the candidates need to sustain their performance to achieve the objectives of the organisation. Therefore, IMTs are essential tools in job interviews should be evaluated constantly. 
TABLE 1: Aspects of Impression Management Tactics

\begin{tabular}{lll}
\hline NO & IMT ASPECT & \multicolumn{1}{c}{ DEFINITIONS } \\
\hline 1 & Self-focused & $\begin{array}{l}\text { Candidates focus interviewer on themselves and convince the } \\
\text { interviewer of their qualities in the interview conversation. }\end{array}$ \\
2 & Self-presentation & $\begin{array}{l}\text { Candidates point out their capabilities and create a positive } \\
\text { impression on the interviewers. }\end{array}$ \\
4 & Exemplification & $\begin{array}{l}\text { Candidates convince the interviewers that they can be a good } \\
\text { example to others. }\end{array}$ \\
5 & Enhancement & $\begin{array}{l}\text { Candidates take responsibility for their past achievements. } \\
\text { are set by a supervisor in the workforce. }\end{array}$
\end{tabular}

Source: Goffman (1959; 1972)

IMTs, thus, are construed as efforts to embody a precise writing or speaking approach to build an optimistic reflection of oneself to an intended individual (Goffman, 1959; 1972). Schlenker (2003) indicated that IMTs are form of conduct exercised to convince people. If a candidate depicts an incorrect impression to an interviewer, the possibility of being selected for a job will be diminished. IMTs are divided into five categories: self-focus, self-presentation, exemplifications, entitlements, and enhancements (Goffman, 1959; 1972). This framework of IMT will be used to analyse the candidates' interactions in job interviews.

Schlenker (2003, p.23) concluded that IMTs generate useful insights regarding "an individual, a thing, a crowd or an establishment by self-evaluating in a societal discourse", and Pontari and Schlenker (2004); Dillard et al (2009) proposed that IMTs can be demonstrated in daily situations where individuals communicate through body language and verbal means. Schlenker (2003) also noted that IMTs are forms of cognition that improve the alliance between an interviewer and candidate. Similarly, Uitdevilligen (2005) noted that IMTs can provide a mirror view of oneself to an interviewer.

Steven and Kristof (1995) also noted that the standard interview questions played important roles in evaluating the IMTs performance of candidates: these cover selfintroductions, strengths and weakness, the purpose of hiring, how to encounter issues or challenges, and their future plans. These questions can be suitable for fresh graduates to answer questions based on the minimal experience gained in universities or colleges. Similarly, Matthew and Nanette (2007) noted that standard interview questions are essential in job interviews as certain questions can evaluate the performances of candidates. Therefore, they concluded that for hiring, it would be necessary to use suitable questions to evaluate IMTs of fresh graduates. Steven and Kristof (1995) added that politeness or respect might also serve to create a positive impression of the person, although all five aspects of IMTs were of paramount importance.

Although Goffman $(1959,1972)$ did not provide any sample utterances for each aspect of IMT, the definitions supplied are enough to provide guidelines for experienced interviewers to evaluate a candidate's performance in a job interview based on observations. 
Krishnan and Srinivass (2014) examined interactions in professional job interviews using the four aspects of IMTs namely self-focus, self-presentation, exemplification, and entitlement, based on the definitions offered by Goffman $(1959,1972)$ as shown in Table 2.

TABLE 2: Sample Utterances of IMT

\begin{tabular}{ll}
\hline \multicolumn{1}{c}{ IMT } & \multicolumn{3}{c}{ SAMPLE UTTERANCES } \\
\hline SELF-FOCUSED & ... ALSO FOCUS ON MY PUNCTUALITY \\
& AND TEAM WORK, AND I CAN \\
& TOLERATE WITH ATTITUDE PEOPLE \\
& WORK CLOSELY... \\
SELF- & ..ALWAYS TRYING MY LEVEL BEST TO \\
PRESENTATION & COMPLETE MY TASK WITHIN THE TIME \\
& FRAMEWORK OR ELSE I AM NOT A \\
EXEMPLIFICATION & GOOD EMPLOYEE \\
& ..WHEN YOU FOLLOW WHAT YOUR \\
& MANAGER SAYS THEN OTHERS WOULD \\
& FOLLOW IN YOUR FOOTSTEPS, AS \\
& SIMPLE AS THAT \\
ENTITLEMENT & I CAN WORK CLOSELY WITH MY \\
& PARTNER BY SHOWING MY FULL \\
& COMMITMENT \\
\hline
\end{tabular}

Table 2 shows the sample of bold utterances by the study of Krishnan and Srinivass' (2014) and the present study focuses on these five aspects of IMTs mentioned above. As for enhancement, the selection of accurate utterances is solely focused on Gofman's (1959, 1972) definition. Krishnan and Srinivass (2014) have noted that an interviewee's depth of understanding of the definition of IMTs and experience in job interviews can help candidates to listen attentively and later evaluate their performances in the aspect of enhancement.

Hence, it is evident from the above views that a candidate who utters an erroneous response in a job interview will hinder his/her chances of being selected. Hence, a candidate has to produce the appropriate utterances based on the questions or circumstances. Generally, scholars confirm that applicants should apply various IMTs in job interviews (Erdogan, 2005; Raja \& Saba, 2012).

Past Studies on Impression Management Tactics

Several studies have been done on IMTs. Wills (2008) studied two specific aspects of IMTs, namely, "distortion of narratives" and "graph manipulation" (p.12). He found that IMTs are vital to highlight the expected words of a message spoken to influence the listeners. In an analysis by Ahmad (2011) it was found that IMTs in job interviews can be articulated linguistically, negatively, and positively. Correspondingly, Parveen (2011) found that IMTs would be able to build confident personalities in generating a convincing impact on interviewers. Interestingly, Mor and Winquist (2002) found that the specific meta-analysis resulted in 226-dimensional outcomes that emphasised the connection with self-focus awareness that appeared to be associated with adverse consequences. The most striking result was found in the study conducted by Singh and Choubisa (2010) that revealed 13 of the 90 participants failed to finish the post-meditation description on self-focus. In another analysis by Walther and Malcolm (2002) revealed that tactical self-presentation was applied 
to garner greater advantages and reduce mistakes. Similarly, Ellison et al. (2006) conducted a study on the self-presentation practices of users related to a social media dating platform. They found that it was easier to articulate their thoughts, ideas and hopes by using social media rather than by face-to-face encounters in the dating process.

In the theory of IMTs, it has been found that a vigilant candidate facing an interview will succeed in applying his/her personality effectively whereas an insipid personality is generally not regarded positively by the interviewer. Steven and Kristof (1995) stated that privileges allude to candidates who had performed well previously were described in the interview. A further study was reported by Kristof, Franke, and Barrick (2002) that a big disparity existed in the educational advantages regarding the participants' academic degrees and gender. Nevertheless, the results revealed that women appeared less advantaged in the first year but were more motivated. In line with Steven and Kristof (1995), Greenberger et al. (2008) found that undergraduates developed as they desired that teachers ought to provide time for relaxation to obtain good grades. Further, Huff cut (2011) reported that interviewees should have knowledge of IMTs that could be applied in job interviews.

Notably, there were similar studies done by Roulin et al (2015) on honest and deceptive impression management in employment interviews. Also, Roulin (2016) examined interviewers' perceptions of IMT management in employment interviews. In another analysis, Lars and Fanny (2019) conducted a study on IMTs among native and non-native speakers of four languages and found that speaking various languages may create a good impression. The above studies reported that there is a lack of IMTs in job interview evaluations and IMTs studies should be constantly conducted to determine whether the candidates meet current job demands. In line with Ahmed et al (2019); Roulin et al (2015); Roulin (2016); Lars and Fanny (2019); Noor et al (2017) who had studied the job interview skills of future engineers based on the application of appraisal analysis assessment and verbal impression management. It was found that future engineers should have certain important elements such as linguistic competence (i.e., correct use of words and phrases), good communication skills, and IMT to get jobs. In line with Noor et al (2017); Fant and Lundell (2019) found that due to intercultural differences between the native and non-native speakers, selfpresentations had few variations based on local patterns of behaviour.

There were several studies done on employability skills. Tanius et al (2019) conducted on the employability skills performance of business graduates in Malaysia. Rahman et al (2019) explored the perceptions of employers on communication skills among fresh graduates. Other studies were conducted by Kenayathulla et al (2019) on the gaps between competence and importance of employability skills and Majid et al (2020) on the employability skills among students of public higher-education institutions in Malaysia. All these studies were conducted with similar objectives but with different methods; SPSS tests such as ANOVA, descriptive analysis, and SEM tests. The findings show that the issue of Malaysian fresh graduates cannot be solved unless they have mastered their communications skills. They need to have high competence in the English language especially in the use of appropriate utterances then would be easier to evaluate the candidates' employability skills and IMTs in job interviews.

While a few investigations have been done on other aspects of IMTs, hardly any research has been attempted on the five aspects of IMTs. The present study has been conducted to evaluate whether fresh graduates used IMTs appropriately in professional communications in job interviews. 


\section{Method}

\section{Setting}

Permissions were obtained from the participating organisations, candidates, the university and the interviewer who conducted the interviews. Semi-structured interviews with the interviewer and the candidates were arranged by getting verbal permissions from the authorised body. There were terms and conditions mentioned as personal details were strictly confidential

The organisation, which was a provider of technical services in telecommunications was located in Kuala Lumpur, Malaysia. Emails were sent to the organisation that dealt with customer services, and the organisation agreed to participate by allowing the collection of data. The organisation conducted interviews for 25 positions in telemarketing and provided the researchers with the interview transcriptions.

\section{Participants}

Twenty-five fresh graduates participated in the present study who were of different races and gender between the ages of 23 and 25 years. For a qualitative study, Charmaz (2006, p.114) suggested that " 25 participants are adequate for smaller projects". Ritchie et al (2003, p. 84) noted that qualitative samples often "lie under 50"; although Green (2009, p.120) mentioned that "the experience of most qualitative researchers is that in interview studies little that is 'new' comes out of transcripts after you have interviewed 20 or so people". Therefore, twenty-five fresh graduates were adequate for the present study. They had graduated from public universities in various courses such as Economics, Management, Marketing, and Business Administration. They were required to undergo three stages of the interview processes: first, essay writing in English using a computer; second, a group discussion on situational topics related to the workplaces; and third, face-to-face interviews. However, due to the ongoing Covid-19 pandemic, the interview was conducted via Google Meet. The interviewer was also one of the participants in this study and was given the IMT evaluation form to evaluate the candidates' performance. The interviewer had more than 25 years of experience and made decisions on hiring the staff.

\section{Measures}

Firstly, an interview evaluation form was adapted from a study by Krishnan and Srinivass (2014) on IMTs. The evaluation form consisted of four aspects of IMT (i.e., self-focus, self-presentation, exemplification, and entitlements). However, for the present study, enhancement, was added as other aspects of IMTs, due to the issues highlighted in the National Graduate Employability Blueprint 2012-2017. The enhancement aspect of IMT has been categorised into two criteria based on Goffman's $(1959,1972)$ definition (see Table 1).

Creswell (2018) noted that Likert-scale of 5-7 can be used to evaluate personality traits, performances or perceptions for qualitative studies. Lincoln and Guba (2000), supported by Yin (2004) also noted that using percentages in evaluating one's performance, perception, or possible responses, it may not be necessary to use an SPSS tool. However, the analysis can be done in a percentage form that determines the participant's performance, especially in spoken data.

Therefore, the interview evaluation form was developed by using a five-point Likertscale to indicate poor, fair, average, good, and excellent. A content validity analysis was performed with three human resource managers to ensure its reliability to evaluate the candidates' IMTs performance in the interviews. The agreement was found to be higher than 
$90 \%$, that indicated the researcher could use the IMTs evaluation questionnaire (Lincoln \& Guba, 2000).

Secondly, a set of standard interview questions was used by the interviewer. These questions consisted of the five common aspects of IMTs expected by the organisation namely self-introduction, strength, weakness or achievements, the purpose of hiring, plans or goals for five years, and how to handle the problems or issues encountered by fresh graduates. Matthew and Nanette (2007) observed that to evaluate certain skills in job interviews, standard interview questions play important roles in portraying their skills, talents, capabilities, and other matters required by particular organisations. For the present study, the participants had to answer questions like 'why we should hire you', that was chosen as the theme for the analysis to evaluate the candidates' IMTs in job interviews. The theme was also chosen based on the emergence of the data as Creswell $(2018$, p.23) noted that spoken data "speaks itself"" and analysis can be done based on the data.

Thirdly, semi-structured interviews were conducted with the interviewer as well as the candidates to know how the candidates performed in the and their preparedness and confidence in answering the interview questions. This interview was conducted with the special arrangement and permission from the authorised body. The semi-structures interview questions were adopted and modified from the studies of (Krishan et al., 2017; Zainuddin et al., 2019).

\section{Data Collection and Analysis Procedures}

The job interview data were recorded by the interviewer and transcribed by the researcher. and were analysed qualitatively using NVIVO and IMT theory (Goffman, 1959; 1972). The analyses were divided into three phases.

In the first phase, data were collected by the interviewer using the interview evaluation forms based on the different aspects of IMTs. Thereafter, the evaluation was calculated in the form of a percentage, as Yin (2004) noted that in qualitative studies frequency and percentage can be included in the analyses.

The second phase involved the recording, transcription, and categorisation of the job interview data according to the definitions of IMTs (Goffman, 1959, 1972). The utterances were selected based on the different categories from the evaluation form. The sample occurrences were chosen based on those that were found in the study by Krishnan and Srinivass (2014), including the four aspects of self-focus, self-presentation, exemplification, and entitlement. However, enhancement was still solely based on the definitions of IMTs by Goffman (1959, 1972). In line with Goffman's $(1959,1972)$ definition, the selected occurrences were verified for accuracy by HRM and language experts to ensure the transcription, coding, and selection of sample occurrences were accurate: one suitable excerpt was selected for each of the four aspects (Li, 2002). And the third phase was, semistructured interviews with the interviewer as well as the candidates. Abbreviations were used for the interviewer (IR) and candidates (C) in the reporting.

\section{Analysis and Discussions}

The analysis is presented in two sections. The first is the results of the interview evaluation form based on the five aspects of IMTs. The second on the theme "Why should we hire you?" is shown by a few samples of occurrences based on the five aspects of IMTs. Table 3 shows the distribution of IMTs for the 25 candidates. 
TABLE 3: The distribution of IMT of Candidates

\begin{tabular}{|c|c|c|c|c|c|c|}
\hline 1 & SELF-FOCUSED & POOR & FAIR & AVERAGE & GOOD & $\begin{array}{c}\text { EXCELLE } \\
\text { NT }\end{array}$ \\
\hline (a) & $\begin{array}{l}\text { Candidate makes strong and } \\
\text { lasting impression in } \\
\text { interview (by answering } \\
\text { questions) }\end{array}$ & $\begin{array}{l}\text { C3, C8, } \\
\text { C19, C23, } \\
\text { C24 }\end{array}$ & $\begin{array}{c}\text { C11, C2, } \\
\text { C6, C7 }\end{array}$ & - & - & - \\
\hline (b) & $\begin{array}{l}\text { Candidate responds } \\
\text { enthusiastically to questions } \\
\text { asked }\end{array}$ & $\begin{array}{c}\text { C4, C20, } \\
\text { C17, }\end{array}$ & $\mathrm{C} 13, \mathrm{C} 14$ & $\begin{array}{c}\text { C1, C5, } \\
\text { C15, C25 }\end{array}$ & - & - \\
\hline (c) & $\begin{array}{l}\text { Candidate confident of } \\
\text { capabilities by answering } \\
\text { questions accurately }\end{array}$ & $\mathrm{C} 10, \mathrm{C} 12$ & $\begin{array}{c}\text { C16,18, } \\
\text { C19 }\end{array}$ & $\mathrm{C} 21, \mathrm{C} 22$ & - & - \\
\hline \multicolumn{2}{|c|}{ Total (\%) } & $10(40 \%)$ & $9(36 \%)$ & $6(24 \%)$ & - & - \\
\hline 2 & SELF-PRESENTATION & POOR & FAIR & AVERAGE & GOOD & $\begin{array}{c}\text { EXCELLE } \\
\text { NT }\end{array}$ \\
\hline (a) & $\begin{array}{l}\text { Candidate is dressed } \\
\text { appropriately and creates a } \\
\text { good first impression }\end{array}$ & $\begin{array}{l}\text { C3, C4, } \\
\text { C5, C6, } \\
\text { C7, C15, } \\
\text { C16, C17 }\end{array}$ & $\begin{array}{c}\text { C18, C19, } \\
\text { C25 }\end{array}$ & $\mathrm{C} 24$ & - & - \\
\hline (b) & $\begin{array}{l}\text { Candidate e employs } \\
\text { appropriate hand gestures } \\
\text { and body language to engage } \\
\text { interviewer's attention }\end{array}$ & $\begin{array}{l}\mathrm{C} 8, \mathrm{C} 9 \\
\mathrm{C} 10, \mathrm{C} 11 \\
\mathrm{C} 12, \mathrm{C} 13 \\
\mathrm{C} 14\end{array}$ & $\begin{array}{l}\text { C1, C2, } \\
\text { C20, C21, } \\
\text { C22, C23, }\end{array}$ & - & - & - \\
\hline & Total (\%) & $15(\%)$ & $9(\%)$ & $1(\%)$ & - & - \\
\hline 3 & EXEMPLIFICATION & POOR & FAIR & AVERAGE & GOOD & $\begin{array}{c}\text { EXCELLE } \\
\text { NT }\end{array}$ \\
\hline (a) & $\begin{array}{l}\text { Candidate's answers to } \\
\text { questions are thoughtful and } \\
\text { meaningful }\end{array}$ & $\begin{array}{l}\mathrm{C} 25,24 \\
\mathrm{C} 23, \mathrm{C} 22 \\
\mathrm{C} 21\end{array}$ & & - & - & - \\
\hline (b) & $\begin{array}{l}\text { Candidate's level of } \\
\text { understanding and maturity } \\
\text { is impressive }\end{array}$ & $\begin{array}{l}\mathrm{C} 1, \mathrm{C} 2 \\
\mathrm{C} 3, \mathrm{C} 4 \\
\quad \mathrm{C} 5\end{array}$ & & - & - & - \\
\hline (c) & $\begin{array}{l}\text { Candidate's ability can be } \\
\text { seen by sharing his/her } \\
\text { responsibility so others can } \\
\text { model themselves on the } \\
\text { candidate }\end{array}$ & $\begin{array}{l}\text { C15, C16, } \\
\text { C17, C18, } \\
\text { C19 }\end{array}$ & $\mathrm{C} 14, \mathrm{C} 15$ & - & - & - \\
\hline (d) & $\begin{array}{l}\text { Candidate is able to view } \\
\text { ideas from different } \\
\text { perspectives }\end{array}$ & $\begin{array}{l}\text { C6, C7, } \\
\text { C8, C9, } \\
\text { C10 }\end{array}$ & $\begin{array}{c}\mathrm{C} 11, \mathrm{C} 12 \\
\mathrm{C} 13\end{array}$ & - & - & - \\
\hline & Total (\%) & $20(\%)$ & $5(\%)$ & - & - & - \\
\hline 4 & ENTITLEMENTS & POOR & FAIR & AVERAGE & GOOD & $\begin{array}{c}\text { EXCELLE } \\
\text { NT }\end{array}$ \\
\hline (a) & $\begin{array}{l}\text { Candidate answers truthfully } \\
\text { and has no problem in } \\
\text { admitting he/she doesn't }\end{array}$ & $\begin{array}{l}\text { C16, C17, } \\
\text { C18, C19, } \\
\text { C20 }\end{array}$ & $\begin{array}{l}\text { C11, C12, } \\
\text { C13, C14, } \\
\text { C15 }\end{array}$ & - & - & - \\
\hline
\end{tabular}


know the answers to certain questions

(b) Candidate answers questions professionally to show his/her is serious in getting a $\mathrm{C} 21, \mathrm{C} 22$ $\mathrm{C} 23, \mathrm{C} 24$, job

(c) Candidate portrays a positive -image by expressing he or C25 she is goal orientated

\begin{tabular}{|c|c|c|c|c|c|c|}
\hline & she is goal orientated & C10 & $\mathrm{C} 25$ & & & \\
\hline \multicolumn{2}{|r|}{ Total (\%) } & $15(\%)$ & $10(\%)$ & - & - & - \\
\hline \multirow[t]{2}{*}{5} & ENHANCEMENT & POOR & FAIR & AVERAGE & GOOD & EXCELLE \\
\hline & & & & & & $\mathbf{N I}$ \\
\hline \multirow{2}{*}{ (a) } & Candidate is able to show & C11, C12, & C1, C2, & - & - & - \\
\hline & $\begin{array}{l}\text { that he or she knowledgeable } \\
\text { in tackling a given situation }\end{array}$ & $\begin{array}{l}\text { C13, C14, } \\
\text { C15 }\end{array}$ & $\begin{array}{l}\text { C3, C4, } \\
\text { C5 }\end{array}$ & & & \\
\hline \multirow[t]{3}{*}{ (b) } & Candidate is self- reliant and & C6. C7, & $\mathrm{C} 21, \mathrm{C} 22$, & C16, C17, & - & - \\
\hline & able to think out of the box & $\begin{array}{l}\text { C8, C9, } \\
\text { C10 }\end{array}$ & $\begin{array}{l}\text { C23, C24, } \\
\text { C25 }\end{array}$ & $\begin{array}{l}\text { C18, C19, } \\
\text { C20 }\end{array}$ & & \\
\hline & Total (\%) & $10(\%)$ & $10(\%)$ & $5(\%)$ & - & - \\
\hline
\end{tabular}

Table 3 shows the distributions of the IMTs among the twenty-five candidates on the five aspects of IMTs and the rating of the candidates are from poor, fair, good, average to excellent. The dash (-) shows that the category was not fulfilled.

The aspect of self-focus included three criteria: candidates had to make a strong and lasting impression in the interview, respond enthusiastically to the questions asked, and demonstrate confidence in their capabilities by answering questions accurately. The results show that all 25 candidates were in the poor $(n=19 ; 60 \%)$, fair $(n=9 ; 36 \%)$ and average $(n=6 ; 4 \%)$ categories.

For self-presentation, there were two criteria on which candidates were assessed. It was found that the candidates in the first criterion were in the poor category $(n=15 ; 60 \%)$, fair category $(n=9 ; 36 \%)$ and average category $(n=1 ; 4 \%)$. Concerning the aspect of exemplification, it was found that the candidates were in the poor category $(n=20 ; 80 \%)$ for the first three criteria and - average category $(n=5 ; 20 \%)$ for the next two criteria. On the aspect of entitlement, it was found that the candidates were in the poor category $(n=15 ; 60 \%)$ for all the criteria, whereas the fair category $(n=10 ; 40 \%)$ covered two criteria. As for the enhancement, the results showed that the candidates were in the poor $(n=10 ; 40 \%)$ and fair $(n=10 ; 40 \%)$ categories for two criteria, whereas for the average $(n=5 ; 20 \%)$ there was only one criterion.

The results obtained from the evaluation of IMTs showed that the candidates were not able to use IMTs appropriately in job interviews. Overall, there was no candidate in the good and excellent categories in the job interviews. As reported by the study of Lars and Fanny (2019) that IMTs plays an important role in the selection process. Therefore, with the above IMTs, the organisations would easily provide job opportunities for the candidates.

The sample bolded utterances of IMTs are presented below on the theme "Why should we hire you?" are from the poor category. Interviewees tried to convince the interviewer of their IMTs qualities in the interview conversations. 


\section{Poor Candidates}

C3 ...actually... I am good person...

C4 ...I think I am qualified...

C19 ...well if my resume is selected which shows that I am almost hired...

C3, C4, and C19 did not mention any of their qualities that could have convinced the interviewer. C3 said, "I am good person," which portrayed one of the qualities, but the answer was not convincing. Similarly, C4 said, "I think I am qualified," was a very strong statement that demonstrated C4's confidence, but perhaps more could have been said. C19 was better than C3 and C4 by stating, "if my resume is selected which shows that I am almost hired," that depicted C19's overconfidence and thus did not convince the interviewer as the answers were blunt.

\section{Fair Candidates}

C2 Well...I have proper qualification and that shows I am qualified and also, I have some qualities...

C6 I have specific qualities required by your organisation and you can hire me...

C7 ...hmmm... I think I am suitable person to work here...moreover my qualification speaks.

There were similarities in the answers among $\mathrm{C} 2, \mathrm{C} 6$, and $\mathrm{C} 7$ as they mentioned their qualities and qualifications. As they had proper qualifications, they expressed they should be considered and hired. However, they did not demonstrate their qualities.

\section{Average Candidates}

C1 ...I believed that my good attitudes would be suitable for the company and I think I am very much suitable...you can hire me

C5 ...I have certain good qualities which suitable for your organisation and I think I will follow... what my manager said...

C15 ...actually...I am hardworking person with good qualities and I think you can hire me...

C1 said that $\mathrm{s} /$ he had specific qualities but failed to illustrate further as to why s/he should be hired. However, C1 was very confident in stating, "I think I am very much suitable...you can hire me," suggesting that perhaps $s /$ he could have mentioned the qualities that would help the interviewer to consider her to be hired based on whether she could fit into the organisation. Similarly, C5 answered, "I have certain good qualities," but did not illustrate what the qualities were. Nevertheless, C5 said, "I think I will follow... what my manager said..." that could have been one of the qualities that C5 obeyed his/her manager. Perhaps, C15 could have said more, but the candidate said, "I am hardworking person with good qualities and I think you can hire me," that was almost the same as C1's response, without elaborating the qualities to indicate their 'hardworking' characteristics as they were very confident and actively answering the question.

For self-focus, none of the candidate was in the good or excellent category. The candidates were not able to demonstrate their qualities such as being team players, punctual, polite, calm, or good listeners. If the candidates had demonstrated these qualities, they could have convinced the interviewer and might have been hired. This finding concurs with a study 
by Mor and Winquist (2002) that candidates need to create an awareness in the interviewer to indicate they have certain qualities to be hired as they can fit into the organisation.

\section{Self-presentation Poor Candidates}

C8 $\quad$...sir...I am the person who like to respect...so can consider me...

C16 ...actually I do not know what to say but I am capable person...so I am hired (laughs)

C17 ...I always have a positive thought ...

C8 said, "I am the person who like to respect," which showed a good impression of C8, who also said to the interviewer, "can consider me." It is apparent that C8 was trying to portray a good impression towards the interviewer by mentioning "can consider me." This is similar to C16, who said, "I am capable person and I am hired," strongly stating that s/he should be considered and hired. C17 said, "have a positive thought," that meant to create a good impression by highlighting that quality.

\section{Fair Candidates}

C18 I have knowledge, can listen to people and able to find solution so I think I am suitable person

C19 ...I do have a positive thought that I can do give my best to any organisation...

C25 ...I can adjust to the situation, understand and work with people and I think I am qualified

C18, who said, "have knowledge, listen to people, find solution and suitable person," demonstrated creating a good impression to the interviewer. C19 said, "positive thought and give my best," which was also meant to create a favourable impression to the interviewer, whereas C25 said, "adjust to the situation, understand and work with people and I am qualified," that were promising utterances.

\section{Average Candidates}

C24 ...I am the person who like to create a positive atmosphere and willing to listen to people who have problem...

As for the average, there was only C24, who said, "like to create a positive atmosphere and willing to listen to people who have a problem," that was an attempt to make a good impression. As Goffman $(1959,1972)$ said that creating a good first impression can be accomplished by employing good interaction with the interviewer. C8, C17, C18, C19, C25, and C24 attempted to provide some information to answer the question, but it was not elaborated by giving extensive information. They were unable to create the desired impression due to limited linguistic competence, and as noted in the study by Noor et al. (2017) that words and phrases are important in portraying IMTs. 


\section{Exemplifications \\ Poor Candidates}

C3 ...l can do my work as others do in a good way...well you can hire me

C4 ...l am good example to your company so you can hire me

C5 ...well hire me first I can be a good example...

C3 and C4 said that they would work like "others and good example;" therefore, they were implying they should be hired but C5 strongly said, "hire me first and I can be a good example."

\section{Fair Candidates}

C11 ...I was good example being a leader during my university time and I think I can be a good leader and (laugh) so no regret if you hire me...

C12 ...sir, I am down to earth and I can gel with all and you may hire me...

C13 (laughs) hmmm I am a good example of the university student and you can hire me...

C11 said that s/he was a "good example during the university," that demonstrated that $\mathrm{s} / \mathrm{he}$ could be a good leader, and therefore, s/he should be hired.C12 said s/he was "down to earth," that reflected that $s /$ he could tolerate any situation and people in the workplace. C13 said, "I am good example of the university student." C11, C12, and C13 demonstrated that they could be examples of leadership, thus emphasising they should be hired. However, they were not in the average, good or excellent categories, that reflected they could have said more.

\section{Entitlements}

\section{Poor Candidates}

C21 ...when I was a leader in one of the projects...I did many jobs...so the involvement may help you to hire me

C22 ...I had experience but my experience may help ...

C23 ...actually...I have an experience and I know how to be in an organisation...

As for entitlements, C21 said, "I was a leader in one of the projects.... I did many jobs... involvement..." thus creating a positive image by expressing that $\mathrm{s} / \mathrm{he}$ was a leader and capable of handling many tasks. In line with C21, C22 mentioned, "experience may help," also created a positive impression, but $\mathrm{s} /$ he did not demonstrate what experience $\mathrm{s} / \mathrm{he}$ had from the previous organisation. Similarly, C23 said, "I have an experience and I know how to be in an organisation," that reflected his/her experience, had moulded him/her to be suitable to the organisation as a staff. C21 was better than C22 and C23 although s/he was still classified in the poor category as the interviewer was anticipating more answers from him/her.

\section{Fair Candidates}

C23 I used to involve in many projects and those projects build me as a good staff and I think that may help to hire in this organisation...

C24 ...sir...my past experience has taught me a good lesson and I have those qualities to hire me...

C25 ...my professional involvement may decide to hire me.... 
C23 said, "involve in many projects" and "those projects build me as a good staff," that created a positive image as a job orientated person by implying that $s /$ he could be an example to other staff. C24 said, "my past experience has taught me a good lesson" and "I have those qualities," thus portraying to be a job-orientated person. However, C25 said, "my professional involvement may decide to hire me," was a strong statement that displayed his/her confidence. Regarding entitlements, no example was found from the fair candidates.

In general, fair candidates spoke about their experiences as reasons to hire them, but they were not creating favourable impressions. Perhaps they could have elaborated more by relating that types of experience they had gained in their previous work. Similarly, fair candidates also mentioned their experiences and involvements, but they attempted to create favourable impressions by stating that their involvement prepared them to guide others and had taught them valuable lessons. This finding agrees with a study by Lars and Fanny (2019), that revealed language, use of words or phrases may create good impressions in interactions.

\section{Enhancements \\ Poor Candidates}

C6 ...I could any work ....

C7 ...I can work and perform...

C8 ...I can handle the situation...

In general, C6, C7, and C8 used similar phrases and said "I could do any work, perform and handle the situation," but none of them illustrated what they could do. They should have answered $\mathrm{c}$ the question and demonstrated their knowledge.

\section{Fair Candidates}

C2 ...actually, I can handle the task but I need some guidance...

C3 ...well...if you assign any job, I could do...

C4 ...l can do any work with a good supervision...

The fair candidates answered slightly better than the poor candidates. C2 said, "can handle the task but I need some guidance," that demonstrated a lack of confidence. C3 said, "if you assign any job, I could do," was not said clearly. C4 said, "can do any work with good supervision," was similar to $\mathrm{C2}^{\prime}$ 's response, that showed a lack of confidence.

\section{Average Candidates}

C17 ...I can work with full responsible but under good supervision...

C18 Sir...(laughs) I can work with the deadline in any projects are given to me

C19 I am sincere person and dedicated to work with full responsibility....

C17 said, "full responsible but under good supervision," that demonstrated the capability of being responsible and s/he should be hired. C18 said, "can work with the deadline in any projects," that also demonstrated s/he could work within a time framework and showed her knowledge in handling projects. C19 said s/he was a sincere person and dedicated with "full responsibility," which was similar to C17, who demonstrated her dedication and responsibility in completing tasks. As for the enhancements, poor and fair candidates were not able to think out-of-the-box and possessed little knowledge to tackle the question properly. 


\section{An Analysis on The Interviewer and the Candidates}

The responses on the IMT from the interviewer were summarised as follows:

"...the candidates were under the category of poor and average as you could see from the evaluation form..."

"...one of the reasons is they were not aware the IMT is one of important tools in job interviews..."

"...most of the candidates were not able to carry out professional communications with the good English language. That could be one of the reasons why they were not under the category good and excellent..."

"the education institutions must play important role to educate these students to aware that not only academic qualifications are important in getting a job, other skills are considered too to be hired which is IMT..."

It was found that most of the candidates were not able to cover all the five aspects of IMTs. They were also unable to carry out professional communications due to their poor English language. The finding is consistent with the study conducted by Holmes and Riddiford (2009) that revealed professional communications is one of the essential tools in job interviews.

Besides the interviewer, the candidates' responses were summarised as follows:

"...frankly speaking, were not taught what is IMT and it should be taught in the colleges and universities..."

"...we know how to impress the interviewer but we did not know there are many tactics to impress the interviewer..."

"...we realised that we have poor English language proficiency and proficiency helps us to carry out professional communication..."

"...due to language barriers, we could not have professional communications, perhaps we should learn how to speak confidently with good English..."

"...lacked of preparation for the job interviews and we were not much exposed to the interview questions..."

It was found that most of the candidates were not taught what are IMTs and lacked exposure to the standard interview questions. The candidates were not able to speak confidently to conduct professional communications due to poor English language proficiency. This finding is consistent with the study by Krishnan and Srinivas (2014). The candidates also voiced out that IMTs should be taught in colleges and universities, hence, the knowledge of IMTs would help us to get a job.

\section{Discussion}

The present study was designed to determine the use of IMTs by fresh graduates in job interviews. The present study has found that none of the candidates were categorised as good or excellent. Most of them were placed in the poor, fair, and average categories. Among the five aspects, exemplification was the highest-ranking, that was in the poor category $(n=20 ; 80 \%)$. The candidates were not able to understand or answer the question. Perhaps they lacked maturity, portrayed their responsibilities to show they could be role models and were not able to see things from different perspectives. The next aspect was the entitlement, for which the candidates were under the poor category ( $n=15 ; 60 \%)$. The candidates might not have understood the questions and perhaps not aware they might be unable to create a positive image to the interviewer. Similarly, the result for self-presentation was also in the poor category $(n=15 ; 60 \%)$, mainly as the attire was not impressive enough. 
Lars and Fanny (2019) observed that the first impression is essential in the professional contexts, this includes engagement with the interviewer in decent body language.

As mentioned by Fant and Lundell (2019), there could be a small variation between the native and non-native speakers due to intercultural differences. This explains why selffocus and enhancement $(n=10 ; 10 \%)$ were placed in the same category, that is poor. In terms of self-focus, the candidates were unable to create a strong impression in their conversation where both speakers were involved. They were also not actively involved in responses, unable to portray confidence, hesitated whether the answer was correct or not rather than creating meaningful impressions in the job interview. As for enhancement, the candidates were not able to show knowledge that indicated understanding of situations and perhaps had limited thinking skills.

Some candidates were placed in the fair and average categories. However, most candidates were placed under the poor category, that indicated they were not able to create a favourable impression in the job interviews. This finding agrees with a study by Jacobs (2003) that mentions candidates should create a favourable impression for the interviewer to be employed.

A possible explanation for poor employability might be due to poor English language proficiency. This study has been found that the candidates were not able to use appropriate words and phrases to show their IMTs to create a favourable impression in the job interviews. A similar finding was reported by Noor et al (2017) that a candidate, who lacked linguistic competence, was not able to utter appropriate words or phrases to portray the IMTs. The present study is also in consensus with Krishnan and Srinivas's (2014) study that IMTs are of paramount importance in job interviews. Another important finding was that these candidates had different abilities that could be viewed differently by employers. Based on their abilities and qualities demonstrated during the interview, it is left to the decisions of the employers as to who can be hired. These qualities may have been the most suitable attributes desired by employers that could provide the best results for their organisations. As mentioned in the studies of Ahmed et al (2019); Roulin et al (2015); Roulin (2016) and Lars and Fanny (2019) that job applicants should apply numerous IMTs in job interviews to show their value and create a favourable impression in job interview evaluations.

As for the semi-structured interviews with the interviewer and the candidates, Holmes (1995); Holmes and Riddiford (2009) have mentioned that professional communications are essential tools in job interviews. They interviewer reported that due to poor English language proficiency the candidates were unable to speak confidently as Ahad (2008) noted that IMT can be expressed linguistically. Further, it was also found that the candidates realised they have poor English language proficiency, Therefore, they were not able to speak confidently and carry out professional communications in job interviews. Hence, they were not able to use IMTs appropriately in job interviews.

To conclude, the findings show that due to poor English language proficiency, the candidates were not able to carry out professional communications in job interviews as mentioned by (Holmes, 1995; Lopez and Fletcher, 2004; Holmes and Riddiford, 2009). If the applicants have IMT, chances of getting job from employers.

\section{Implication}

The findings show that IMTs are one of the essential components in job interviews and there is a high demand for fresh graduates who have strong IMTs in workplaces. This study may create awareness among candidates that educational qualification is an important 
criterion along with the ability to impress an interviewer for success in a job interview. The findings of this study may also serve as a guide for the higher-learning institutions and corporate sectors on what should be emphasised in the curriculum (teaching pedagogy) to improve fresh the performance of graduates in job interviews. Additionally, interview evaluation forms should be improved by organisations and incorporate the IMTs aspects.

In the present study, there were several terms and conditions imposed, especially in collecting the data. This study was limited by the absence of the researcher to observe the interviews.

\section{Conclusion}

This study was conducted to analyse the IMTs used by fresh graduates in job interviews based on the particular theme "Why should we hire you?". In today's era of globalisation, there is a greater demand for specialisation in various fields. Job interviews require candidates to be able to sell their expertise to impress the interviewer through professional communications. Hence, chances and better starting salary might be given to those who have strong IMTs competence. From this study a new method or approach on learning how to perform well in job interviews can be introduced.

As the present study has been limited, future studies need can be conducted to establish non-verbal behaviours by integrating IMTs. This can be done with the linguistic analysis as Abdul (2008); Ahmad (2011) that said IMT can be investigated with concepts such as communication strategies and communicative competence that can be more significant for professional communications.

\section{References}

Ahmed, A. A., Hayfaa, A. T., \& Sandra, W. H. (2019). Work experiences of native Americans: A qualitative study. Journal of Career Development, 8 (2), 105-119. https://doi.org/10.1177/0894845319832129

Ahmad, A. (2011). Impact of impression management on performance rating. Interdisciplinary Journal of Contemporary Research in Business, 3(2), 711729.https://www.academia.edu/30452919/Impact_of_Impression_Management_on_ Performance_Rating

Abdul, F. A. (2008). How to improve the employability of graduates. Business Intelligence Journal, 2(2),288-312.https://doi.org/10.1080/13639080802080949

Charmaz, K. (2006). Constructing grounded theory: A practical guide through qualitative analysis. SAGE Publications, Inc.

Cheung, F., Yeung, D. Y., \& Wu, A. M. (2017). Employees' perception of leadership styles and successful aging in the workplace. Journal of Career Development, 45(6),601-624. https://doi.org/10.1177/0894845317727617

Coffelt, T., Baker, M. J., \& Corey, R. C. (2016). Business communication practices from employers' perspectives. English Publication, 1-27. http://lib.dr.iastate.edu/engl_pubs/117

Creswell, J. (2014). Research design: Qualitative, quantitative, and mixed methods approaches (4th ed.) SAGE Publications, Inc.

Dillard, C., Browning, L. D., Sitkin, S. B., \& Sutcliffe, K. M. (2000). Impression management and the use of procedures at the Ritz-Carlton: Moral standards and dramaturgical discipline. Communication Studies, 51(4), 404-414. https://doi.org/10.1080/10510970009388534 
Ellison, N., Heino, R., \& Gibbs, J. (2006). Managing impressions online: Self-presentation processes in the online dating environment, Journal of Computer-Mediated Communication, 11(2), 415-441.https://doi.org/10.1111/j.1083-6101.2006.00020.x

Fant, L., \& Lundell, F.F (2019). Keeping up appearances: Impression management in native and non-native speakers of four languages, Intercultural Pragmatics, 16(1), 1-25. https://doi.org/10.1515/ip-2019-0001

Foss, K., \& Littlejohn, S. (2008). Theories of human communication (9th ed.). Academic Press.

Greenberger, E., Lessard, J., Chen, C., \& Farrugia, S. P. (2008). Self-entitled college students: Contributions of personality, parenting, and motivation factors. Journal of Youth and Adolescence,37(1), 1193-1204.https://doi.org/10.1007/s10964-008-9284-9

Green, J. (2009). Qualitative methods for health research (2nd ed.). Thousand Oaks, CA: Sage.

Goffman, E. (1959). The Presentation of Self in Everyday Live. Garden City, New York: Doubleday Anchor.

Goffman, E. (1972). Interaction ritual: Essays on face to face behaviour. Allen Lane The Penguin Press, London (reissue of Goffman 1967).

Hamid, M. S. A., Islam, R., \& Hazilah, A. M. N. (2014). Malaysian graduates' employability skills enhancement: an application of the importance performance analysis. Journal for Global Business Advancement, 7(3), 181-197. https://www.researchgate.net/publication/270295771

Holmes, L. (1995). Competence and capability: From confidence trick to the construction of the graduate identity. Paper presented for Beyond Competence to Capability and the Learning Society Conference, UMIST, Manchester. http://www.leeds.ac.uk/educol/documents/000000020.htm

Holmes, J. M. M., \& Riddiford, N. (2009). New zealand's language in the workplace project: Workplace communication for skilled migrants (1st ed.). New Zealand, Victoria: Academic.

Huang, R. (2013). International experience and graduate employability: Perceptions of Chinese international students in the UK. Journal of Hospitality, Leisure, Sport \& Tourism Education, 13, 87-96. https://doi.org/10.1016/j.jhlste.2013.07.001

Huffcutt, A. I. (2010). From science to practice: Seven principles for conducting employment interviews. Journal of Human Resource, 12(3), 1318.https://msu.edu/ morgeson/levashina_hartwell_morgeson_campion_2014.pdf

Jacobs, M. B. (2003). Obsessed with impression management: A critical sociology of body image in capitalist society. Journal of Human Resource, 2(9), 12-23. https://scholarworks.umb.edu/humanarchitecture/vol2/iss2/10

Jensen, I. (2003). Professionalism in intercultural job interviews. Journal of Intercultural Communication, 8, 241-249. https://www.immi.se/intercultural/nr8/jensen-nr8.htm

Kacmar, K. M., Delery, J. E., \&Ferris, G. R. (1992). Differential effectiveness of applicant impression management tactics on employment interview decisions. Journal of Applied Social Psychology, 6(3), 23-41. https://doi.org/10.1111/j.15591816.1992.tb00949.x

Kenayathulla, H. B., Ahmad, N. A., \& Idris, A. R. (2019). Gaps between competence and importance of employability skills: Evidence from Malaysia. Higher Education Evaluation and Development, 13(2) 97-112. 
https://www.emerald.com/insight/content/doi/10.1108/HEED-08-20190039/full/html

Krishnan, I. S., \& Srinivasss, S. (2014). Interaction in professional discourse in job interviews. (Published Masters thesis) University of Malaya.

Krishnan, I. A., Ramalingam, S. J., Hee, S. C., \& Maruthan, E. (2017). The selection practices and recruitments of fresh graduates in local organisation's job interview. Journal of Language and Communication, 4(2), 153-116. https://www.academia.edu/36569540/

Kwok, M. (2004). Disciplinary differences in the perceptions of university graduates and faculty members with respect to the development of general employability skills in undergraduate programs (Doctoral dissertation, The University of Manitoba). https://www.researchgate.net/publication/26409026

Li, W. (2002). What do You Want Me to Say?' On the Conversation Analysis Approach to Bilingual Interaction. Language in Society-Lang Soc,3(1), 02-28.

Lincoln, Y. S., \& Guba, E. G. (2000). Paradigmatic controversies, contradictions, and emerging confluences. In N. K. Denzin \& Y. S. Lincoln (Eds.), Handbook of Qualitative Research.

Lopez, J., \& Fletcher, C.(2004). Social Behaviour and Personality-Fairness of impression management in employment interviews: a cross-country study of the role of equity and Machiavellianism. Psychology Journals, 2(1),47-61. https://doi.org/10.2224/sbp.2004.32.8.747

Madziva, R., McGrath, S., \& Thondhlana, J. (2016). Communicating employability: The role of communicative competence for Zimbabwean highly skilled migrants in the UK. Journal of International Migration and Integration, 17(1), 235-252. https://www.researchgate.net/publication/284625248

Matthew, J. D., \& Nanette, D. (2007). Perfect phrases for negotiating salary and job offers. ISBN 978-981-4646-75-8. McGraw Hill Education.

MHEM. (2019). The national graduate employability blue print 2015-2025. Ministry of Higher Education Malaysia, Putra Jaya Malaysia, ISBN:978-967-0444-43-2.65.

Noor, M. S. N. F., Tab, M. F., \& Kamarulzaman, R. (2017). Exploring Job Interview Skills of Future Engineers: Application of Appraisal Analysis Assessment and Verbal Impression Management. Journal of Technical Education and Training, 9(1). https://publisher.uthm.edu.my/ojs/index.php/JTET/article/view/1405

Mor, N., \&Winquist, J. (2002). Self-focused attention and negative affect: A meta-analysis, Psychological Bulletin,128(4), 638-662. https://pdfs.semanticscholar.org/301e/9cf784ee81ce6499640c264165c4556a56b4.pd $f$

Parveen, K. (2011) Discourse Strategies for Impression Management in job Interviews. (Unpublished master's thesis. University Putra Malaysia, Kuala Lumpur.

Pontari, B., \& Schlenker, B. (2004). The influence of cognitive load on self-presentation: Can cognitive busyness help as well as harm social performance? Journal of personality and social psychology, 78(1) 18-27. https://1092-108. 10.1037//0022-3514.78.6.1092.

Rahman, F. A., Mohamed, H. A., Saidin, K., \& Nasir. (2019). Exploring perceptions of employers on communication skills among fresh graduates. Practitioner Research, 1(2),69-85. https://www.researchgate.net/publication/273756679

Ritchie, J., Lewis, J., \& Elam, G. (2003). Designing and selecting samples. In Jane Ritchie \& Jane Lewis (Eds.), Qualitative research practice. A guide for social science students and researchers (pp.77-108) Thousand Oaks, CA: Sage. 
Roulin, N. (2016). Individual differences predicting impression management detection in Jobinterviews, Personnel Assessment and Decisions,2 (1), 1-14. https://scholarworks.bgsu.edu/pad/vol2/iss1/1

Roulin, N., Bangerter, A., \&Levashina, J. (2015). Honest and deceptive impression management in the employment interview: Can it be detected and how does it impact

evaluations? Personnel Psychology 68(2). 395-444.https://psycnet.apa.org/record/201423191-001.

Sanchez, Y., \& Guo, K.L. (2005). Workplace Communication. Boston, MA: Pearson

Schlenker, B. R. (2003). Self-Presentation: In M.R. Leary and J.P Tangney (Eds.), Handbook of self and identity (p.31) New York, NY: Springer-Verlag.

Singh, K., \& Choubisa, R. (2010). Empirical validation of values in action-inventory of strengths (VIA-IS) in Indian context. Psychological Studies, 55. 151-158.http//: 10.1007/s12646-010-0015-4.

Stevens, C. K., \& Kristof, A. L. (1995). Making the right impression: A field study of Applicant impression management during job interviews, Journal of Applied Psychology, 80 (5),13-22. https://doi.org/10.1037/0021-9010.80.5.587

Tanius, E., Johari, E. T. H., Yulia, A., Heng, C. S., \& Pazim, K. H. (2019). The employability skills performance of business graduates in Malaysia: do employers, graduates and academicians speak the same language?" International Journal of Asian Social

Science, Asian Economic and Social Society, 9(1), 1117.https://ideas.repec.org/a/asi/ijoass/2019p11-17.htm

Turnley, W. B. (2001). Achieving desired images: Exploring the role Self-Monitoring in impression management.Journal of Applied Psychology, 5(2), 9-20. https://doi.org/10.1037/0021-9010.86.2.351

Uitdevilligen. (2005). Resolving the impression management dilemma: The strategic benefits of soliciting others for advice. London, England, Management.

Walther, J. B. (200). Research ethics in Internet-enabled research: Human subjects issues and methodological myopia. Ethics and Information Technology 4, 205-216, https://doi.org/10.1023/A:102136842611

Wills, D. (2008). Perceptions of company performance: A study of impression management. Journal of Applied Psychology, 89(4), 13-19. https://doi.org/10.1108/JMP-10-20120295

Yin, R. K. (2004). The Case Study Anthology, Sage, Thousand Oaks, CA. Zainuddin, S. Z., Pillai, S., Dumanig, F. P., \&Phillip, A. (2019). English language and graduate employability, Education + Training, 61(1), 79-93. https://doi.org/10.1108/ET-06-2017-0089 